\title{
Grass-roots not so green
}

\section{Washington \& San Francisco}

AFTER a summer of growing environmental activism, voters across the United States rejected virtually every 'green' measure on the state ballots in last week's national elections. In the six states where environmentalists had concentrated their efforts, voting went by as much as two to one against referendums that would have stiffened regulations of emission, logging, recycling, pesticides, the nuclear power industry and waterways. All of the most sweeping initiatives - notably California's 'Big Green' proposal and New York's $\$ 2,000$ million environmental bond issue - were defeated.

Supporters of the referendums attribute the losses to massive opposition campaigns sponsored by industry and other opponents.

In Oregon, the oil and chemical industry outspent environmentalists eight to one over a recycling initiative, eventually drowning the measure in a $\$ 2.5$ million television advertising campaign. The less affluent supporters of the referendum were forced to turn to the federal 'fairness doctrine', which requires broadcast media to provide "reasonable opportunity for response" to political advertising. But that typically meant one hour of free pro-initiative air time for every four hours bought by opponents", says Jon Stubenvoll, press secretary for the consumer recycling coalition that sponsored the referendum.

Industry-sponsored advertising also showed a shift towards hard-line tactics. The Oregon recycling initiative had been ahead in the polls, Stubenvoll says, until opponents aired a commercial that implied that restrictions on plastic food wrap could result in outbreaks of botulism, hepatitis and salmonella. "That's hard to fight. Fear is an incredible tool", says David Hamilton, national field director for the US Public Interest Research Group, which helped sponsor some of the initiatives.

Despite the defeat of specific proposals, environmental groups did well in backing the campaigns of proenvironment politicians.

In Congress, pro-environmental candidates picked up 14 seats - 13 in the House of Representatives and one in the Senate - according to Reid Wilson, political director of the Sierra Club. He also calculates a net gain of five state governorships on environmental issues.

With stronger environmental representation at the congressional and state levels, grassroots initiatives of the sort that failed last week may become less necessary, Wilson says. "Initiatives are started because the voters are frustrated by inaction on the part of their elected officials. The more good officials we have, the fewer initiatives we'll need." In California, both major environmental propositions - Big Green (see Nature 347, 323; 27 September 1990) and a timber measure known as Forest Forever - lost last week, but so did their industry-sponsored counter-measures, one proposing compromise regulations on pesticides and another creating timber bonds.

The pattern that emerged across the United States is that virtually "every proposition that called for significant outlays of money was defeated", according to Ralph Cavanagh, energy program director at the Natural Resources Defense Council.

Cavanagh says Big Green was hurt most by opponents who framed the measure as one which would lead to higher food and energy costs.

"If the elections had been held before the Middle East crisis and the budget battles in Congress last month, I think that many of these initiatives would have won", Wilson says. But given that economic uncertainty is likely to be a feature on the political landscape for some time, supporting pro-environment politicians rather than ballot referendums may prove to be a stronger strategy in the future, he says.

Christopher Anderson \& Elizabeth Schaefer

\section{Swiss cut it to the bone}

\section{Munich}

IN a fitting coda to the World Climate Conference in Geneva, the host government announced on 31 October that it intends to pursue what will be one of the world's strictest policies. Swiss environment Minister Flavio Cotti introduced a government proposal for a stiff carbon dioxide tax and other measures aimed at reducing $\mathrm{CO}_{2}$ emissions by around 2.5 per cent before the year 2000 .

Although Switzerland contributes a paltry 0.2 per cent to world $\mathrm{CO}_{2}$ output, the government hopes to set an example to its neighbours. The Swiss plan, which has to be approved by the parliament in mid-1991 in order to take effect, aims to reduce consumption of fossil fuels by imposing huge tax increases. Coal will be taxed at 42 to 105 per cent of the market price, petrol at 15 per cent, heating oil at 23 per cent and natural gas at 20 per cent. And Cotti said, the tax would probably have to be doubled in 1995 to achieve the intended goal.

The $\mathrm{CO}_{2}$ tax, if approved, would be ANIMAL RIGHTS

\section{Dolphin excused military service}

\section{Boston}

WITH the help of public demonstrations, front page newspaper stories, local television reports and a lawsuit, animal rights

\section{IMAGE UNAVAILABLE FOR COPYRIGHT REASONS}

Dolphin draft-up

activists have staved off the prospect of military service for Rainbow, a dolphin at the New England aquarium in Boston. The about double a tax being considered in Germany and several times higher than a tax already in effect in the Netherlands. The only other European country taking a comparable stand, according to a Swiss government official, is Sweden. The official said the tax proposal was received "quite positively" by the parliament and the public, which is also enthusiastic about reducing emissions of nitrogen oxides that are destroying Swiss forests. He expects the proposal to survive in some form despite probable industry opposition.

Ironically enough, it is possible that the parliament will reduce the tax not because it is too high for consumers, but rather because it would bring in too much money - an estimated 1,900 million Swiss Francs (about $\$ 1,500$ million) a year - to the already overflowing government coffers. The government surpluses that have become the norm in Switzerland are not allowed to go above certain levels, so that every new tax must be accompanied by a reduction in an existing tax

Steven Dickman dolphin had been scheduled for transferral to a classified programme in the U.S. Navy which reportedly trains marine mammals for military work. News of the transfer ignited strong popular sentiment, with a former Navy dolphin trainer weighing in on Rainbow's behalf and attacking the Navy's programme.

According to workers at the aquarium, Rainbow, an 11-year-old male, had been put on the transfer list because he showed increasingly aggressive tendencies towards his companions. Aquarium officials have now promised that Rainbow will not be enlisted in the Navy, although what will be done remains unclear. Seth Shulman 